\title{
HUBUNGAN IBU HAMIL DENGAN PREEKLAMSIA BERAT (PEB) TERHADAP ANGKA KEJADIAN BERAT BADAN LAHIR RENDAH (BBLR)
}

\author{
Sri Martini ${ }^{1}$, Rosmala Kurnia Dewi ${ }^{2}$ \\ 1,2 Prodi S1 Kebidanan Fakultas Sains dan Kesehatan Universitas An Nuur \\ Alamat Korespondensi: ${ }^{1}$ tintanaditya@gmail.com; ${ }^{2}$ kurniadewirosmala@ gmail.com
}

\begin{abstract}
ABSTRAK
Hipertensi dalam kehamilan merupakan masalah medis yang masih sering terjadi selama kehamilan dan dapat menimbulkan komplikasi pada kehamilan. Preeklamsia dalam kehamilan dapat mengakibatkan dampak yang bervariasi. Menurut Preeclamsia Foundation dalam American Pregnancy Association (2018) dikatakan bahwa preeklamsia akan menyebabkan darah menjadi tidak cukup menuju plasenta sehingga menimbulkan asupan nutrisi dan oksigen ke janin menjadi berkurang dan berpengaruh terhadap berat badan janin. Tujuan penelitian ini adalah untuk mengetahui hubungan Ibu Hamil dengan Preeklamsia Berat (PEB) terhadap angka kejadian Berat Badan Lahir Rendah (BBLR). Jenis penelitian menggunakan metode penelitian analitik dengan pendekatan retrospektif. Analisa bivariat digunakan untuk mengetahui hubungan terhadap objek penelitian dengan menggunakan uji Spearman Correlation. Penelitian ini dilaksanakan di Rumah Sakit Permata Bunda (RSPB) Purwodadi dengan menggunakan data sekunder rekam medis sebagai data penelitian. Subjek penelitian adalah ibu hamil yang melahirkan dengan sampel 33 responden menggunakan sistem total sampling. Dari hasil penelitian didapatkan Ibu hamil dengan PEB yang melahirkan bayi dengan BBLR sebanyak 14 (82,4\%) dan ibu hamil PEB yang melahirkan bayi tidak BBLR sebanyak $3(17,6 \%)$. Sedangkan ibu hamil tidak PEB yang melahirkan BBLR sebanyak 2 (12,5\%) dan ibu hamil tidak PEB yang melahirkan tidak BBLR sebanyak 14 (87,5\%). Hasil uji Spearman dengan nilai signifikan sebesar $0,000(\mathrm{p}<0,05)$, koefisiensi korelasi sebesar 0,699 yang menunjukkan korelasi yang kuat dan bernilai positip. Hal ini menunjukkan adanya hubungan yang signifikan antara ibu hamil dengan PEB terhadap angka kejadian BBLR.
\end{abstract}

Kata kunci : Preeklamsia Berat, Berat Badan Lahir Rendah

\begin{abstract}
Hypertension in pregnancy is a medical problem that often occurs during pregnancy and can cause complications in pregnancy. Preeclampsia in pregnancy causes various effects. According to the Preeclampsia Foundation in the American Pregnancy Association (2018), it is said that preeclampsia will cause insufficient blood to reach the placenta, which causes the intake of nutrients and oxygen to the fetus to be reduced and affects the fetal weight. The purpose of this study was to determine the relationship between pregnant women and severe preeclampsia (SP) on the incidence of low birth weight (LBW). This research uses analytical research methods with retrospective approach. Bivariate analysis is used to determine the relationship to the object of research using thetest Spearman Correlation. This research was conducted at Permata Bunda Hospital (RSPB) Purwodadi using secondary data from medical records as research data. Research subjects were pregnant women who gave birth with a sample of 33 respondents using a total sampling system. From the results of the study, $14(82.4 \%)$ pregnant women with SP who gave birth to babies with LBW and $3(17.6 \%)$ pregnant women with SP. Meanwhile, 2 pregnant women without SP who gave birth to LBW were $2(12.5 \%)$ and $14(87.5 \%)$ non-pregnant women who gave birth without SP. Spearman test results with a significant value of $0.000(\mathrm{p}<0.05)$ with a correlation coefficient of 0.699 which indicates a strong correlation and a positive value. This shows that there is a significant relationship between pregnant women and SP on the incidence of LBW.
\end{abstract}

Keywords : Severe Preeclampsia (SP), low birth weight (LBW) 


\section{PENDAHULUAN}

Kehamilan dapat berkembang menjadi masalah atau komplikasi setiap saat. Setiap kehamilan membawa resiko bagi ibu maupun janinnya. World Health Organization (WHO) memperkirakan sekitar $15 \%$ dari seluruh wanita hamil akan berkembang menjadi komplikasi yang berkaitan dengan kehamilannya serta dapat mengancam jiwanya juga janinnya.

Hipertensi dalam kehamilan merupakan masalah medis yang masih sering terjadi selama kehamilan dan dapat menimbulkan komplikasi pada kehamilan. Hipertensi dalam kehamilan merupakan salah satu penyebab morbiditas dan mortalitas pada ibu selain perdarahan dan infeksi.

Di Indonesia, kematian ibu didominasi oleh tiga penyebab utama kematian yaitu perdarahan, preeklamsia dan infeksi. Penyebab kematian ibu sekarang cenderung berubah proporsinya dimana perdarahan dan infeksi mengalami penurunan sedangkan preeklamsia mengalami peningkatan. Preeklamsia mempengaruhi $3-5 \%$ dari kehamilan dan bertanggung jawab lebih dari 60.000 kematian ibu dan 500.000 kematian janin per tahun di dunia. Lebih dari $25 \%$ kematian ibu di Indonesia disebabkan preeklamsia. (Kementrian Kesehatan, 2016). Di beberapa Rumah Sakit di Indonesia juga telah terjadi pergeseran penyebab utama kematian ibu yaitu dari kasus perdarahan berubah menjadi kasus preeklamsia.

Preeklamsia dalam kehamilan dapat mengakibatkan dampak yang bervariasi. Preeklamsia adalah suatu keadaan terjadinya kenaikan tekanan darah atau hipertensi yang timbul setelah usia kehamilan 20 minggu dengan disertai edema dan atau proteinuria. Preeklamsia ada 2 (dua) kategori yaitu Preeklamsia Ringan dan Preeklamsia Berat. Dikatakan sebagai Preeklamsia Berat jika terdapat kenaikan tekanan darah >160/140 $\mathrm{mmHg}$. Gejala preeklamsi sering tidak diketahui atau tidak diperhatikan oleh wanita, sehingga tanpa disadari dalam waktu singkat dapat timbul preeklampsia berat bahkan eklampsia.

Menurut Preeclamsia Foundation dalam American Pregnancy Association (2018) dikatakan bahwa preeklamsia akan menyebabkan darah menjadi tidak cukup menuju plasenta sehingga menimbulkan asupan nutrisi dan oksigen ke janin menjadi berkurang dan berpengaruh terhadap berat badan janin.

Preeklamsia juga meningkatkan angka kejadian morbiditas dan mortalitas pada neonatus. Penyebab kematian tertinggi menunjukkan bahwa proporsi neonatal pada kelompok umur 0 -7 hari adalah prematur dan bayi Berat Badan Lahir Rendah (BBLR) sebesar 35\% dan bayi lahir dengan asfiksia sebesar 33,6\%.

Menurut WHO, BBLR adalah berat saat lahir kurang dari 2.500 gram. Berat lahir rendah menjadi masalah kesehatan masyarakat yang berkelanjutan secara global dan signifikan. Bayi dengan BBLR meningkatkan angka kesakitan dan kematian 2 (dua) kali lipat dibanding bayi yang lahir dengan berat 2.500 atau lebih. Di dunia terdapat kejadian BBLR sekitar $15,5 \%$ yang artinya sekitar 20,6 juta bayi BBLR yang lahir setiap tahun. 96,5\% diantaranya terjadi di negara-negara berkembang sehingga menjadi masalah utama di negara berkembang. (WHO,2015)

Indonesia merupakan salah satu negara berkembang pada urutan ketiga sebagai negara dengan prevalensi BBLR tertinggi $(11,1 \%)$ setelah India $(27,6 \%)$ dan Afrika Selatan (13,2\%). Indonesia juga turut menjadi negara kedua dengan prevalensi BBLR tertinggi di ASEAN setelah Filipina (21,2\%). (Supiati, 2016)

Di Jawa Tengah, persentase BBLR pada tahun 2018 sebesar $4,3 \%$, cenderung turun dibandingkan persentase BBLR pada tahun 2017 yaitu 4,4\%. Kabupaten/kota 
dengan persentase BBLR kurang dari 2 persen adalah Demak sebesar 1 persen dan Kudus sebesar 1,2 persen, sementara kabupaten/kota dengan persentase BBLR tertinggi adalah Purbalingga sebesar 9,2 persen. Persentase di kabupaten Grobogan adalah 4,6\%. (Profil Kesehatan Provinsi Jawa Tengah Tahun 2018).

\section{METODE PENELITIAN}

Metode penelitian yang digunakan dalam penelitian ini adalah metode penelitian analitik dengan pendekatan retrospektif. Untuk mengetahui hubungan terhadap obyek penelitian dengan menggunakan analisa bivariat uji Spearman Correlation dengan tingkat kemaknaan $100 \%(\alpha=0,000)$.

Dalam melakukan penelitian hubungan ibu hamil dengan preeklamsia berat (PEB) terhadap angka kejadian Berat Badan Lahir Rendah (BBLR) peneliti menggunakan populasi dari seluruh ibu hamil yang bersalin di Rumah Sakit Permata Bunda Purwodadi pada bulan Juni 2019 sebanyak 33 ibu bersalin. Metode pengambilan sampel adalah dengan total sampling yaitu sebanyal 33 ibu bersalin.

Penelitian ini menggunakan data sekunder berupa catatan rekam medis pasien di Ruang Bersalin Rumah Sakit Permata Bunda Purwodadi yang selanjutnya data akan dilakukan analisa univariat dan bivariat.

\section{HASIL PENELITIAN}

Rumah Sakit Permata Bunda (RSPB) Purwodadi terlatak di Jl. Hayam Wuruk No. 24 Purwodadi Grobogan. RS Permata Bunda Purwodadi merupakan Rumah Sakit Umum yang berorientasi profit tanpa meninggalkan fungsi sosial yaitu Rumah Sakit yang mampu dalam pelayanan tepat guna, inovatif dan efisien dengan didukung sumber daya manusia yang profesional.

RS Permata Bunda Purwodadi mempunyai 4 (empat) jenis pelayanan medis yaitu pelayanan gawat darurat, pelayanan rawat jalan, pelayanan rawat inap dan poli spesialis. RS Permata Bunda Purwodadi juga menjadi Rumah Sakit Rujukan di Kabupaten Grobogan.

Tabel 1 Karakteristik Ibu Hamil Berdasarkan Umur

\begin{tabular}{ccc}
\hline Umur Ibu & Frekuensi & Persentase \\
\hline$<20$ tahun & 3 & 9.1 \\
$20-35$ tahun & 19 & 57.6 \\
$>35$ tahun & 11 & 33.3 \\
\hline Total & $\mathbf{3 3}$ & $\mathbf{1 0 0 . 0}$ \\
\hline
\end{tabular}

Berdasarkan tabel di atas dapat terbaca jumlah ibu hamil dengan umur $<20$ tahun sebanyak 3 responden dengan persentase $9,1 \% \%$, umur 20 - 35 tahun sebanyak 19 responden dengan persentase $57,6 \% \%$ dan umur $>35$ tahun sebanyak 11 responden dengan persentase $33,3 \%$. Jadi karakteristik ibu hamil berdasarkan usia paling banyak pada kelompok umur 20 -35 tahun dan paling sedikit pada kelompok umur $<20$ tahun.

Tabel 2 Karakteristik Ibu Hamil Berdasarkan Pekerjaan

\begin{tabular}{ccc}
\hline Pekerjaan & Frekuensi & Persentase \\
\hline Bekerja & 6 & 18.2 \\
Tidak Bekerja & 27 & 81.8 \\
\hline Total & $\mathbf{3 3}$ & $\mathbf{1 0 0 . 0}$ \\
\hline
\end{tabular}


Berdasarkan tabel di atas dapat terbaca jumlah ibu hamil yang bekerja sebanyak 6 responden dengan persentase $18,2 \%$ dan jumlah ibu hamil yang tidak bekerja sebanyak 27 responden dengan persentase $81,8 \%$. Jadi karakteristik ibu hamil yang digunakan dalam penelitian ini lebih banyak tidak bekerja atau Ibu Rumah Tangga (IRT).

Tabel 3 Karakteristik Ibu Hamil Berdasarkan Paritas

\begin{tabular}{ccc}
\hline Paritas & Frekuensi & Persentase \\
\hline Primipara & 6 & 18.2 \\
Multipara & 27 & 81.8 \\
\hline Total & $\mathbf{3 3}$ & $\mathbf{1 0 0 . 0}$ \\
\hline
\end{tabular}

Berdasarkan tabel di atas dapat terbaca bahwa jumlah ibu hamil primipara 6 responden dengan persentase 18,2\%\% dan ibu hamil multipara 27 responden dengan persentase $81,8 \%$. Jadi dari seluruh responden yang paling banyak adalah ibu hamil multipara.

Tabel 4 Status Ibu Hamil dengan Preeklamsia Berat (PEB)

\begin{tabular}{ccc}
\hline Kejadian PEB & Frekuensi & Persentase \\
\hline PEB & 17 & 51.5 \\
Tidak PEB & 16 & 48.5 \\
\hline Total & $\mathbf{3 3}$ & $\mathbf{1 0 0 . 0}$ \\
\hline
\end{tabular}

Berdasarkan tabel di atas dapat dibaca ibu hamil dengan preeklamsia berat (PEB) sebanyak 17 responden dengan persentase $51,5 \%$, sedangkan ibu hamil tidak PEB sebanyak 16 responden dengan persentase $48,5 \%$

Tabel 5 Berat Badan Lahir Rendah (BBLR)

\begin{tabular}{ccc}
\hline Kejadian BBLR & frekuensi & Persentase \\
\hline BBLR & 16 & 48.5 \\
Tidak BBLR & 17 & 51.5 \\
\hline Total & $\mathbf{3 3}$ & $\mathbf{1 0 0 . 0}$ \\
\hline
\end{tabular}

Berdasarkan tabel di atas dapat dibaca angka kejadian Berat Badan Lahir Rendah (BBLR) sebanyak 16 responden dengan persentase $48,5 \%$, sedangkan yang tidak terjadi BBLR sebanyak 17 dengan persentase $51,5 \%$.

Tabel 6 Hubungan Ibu Hamil dengan PEB terhadap Angka Kejadian BBLR

\begin{tabular}{ccrrrrrrr}
\hline & & \multicolumn{7}{c}{ Kejadian BBLR } \\
\cline { 3 - 8 } & & BBLR & $\%$ & $\begin{array}{c}\text { Tidak } \\
\text { BBLR }\end{array}$ & $\%$ & Total & $\%$ \\
\cline { 3 - 8 } Kejadian PEB & PEB & 14 & $82.4 \%$ & 3 & $17.6 \%$ & 17 & $100.0 \%$ \\
& Tidak PEB & 2 & $12.5 \%$ & 14 & $87.5 \%$ & 16 & $100.0 \%$ \\
\hline
\end{tabular}




\begin{tabular}{lllllll} 
Total & 16 & $48.5 \%$ & 17 & $51.5 \%$ & 33 & $100.0 \%$ \\
\hline
\end{tabular}

Berdasarkan tabel di atas dapat dibaca ibu hamil dengan PEB yang melahirkan bayi dengan BBLR sebanyak 14 responden dengan persentase $82,4 \%$, dan ibu hamil PEB yang melahirkan bayi tidak BBLR sebanyak 3 responden dengan persentase $17,6 \%$. Sedangkan ibu hamil yang tidak mengalami PEB melahirkan bayi dengan BBLR sebanyak 2 responden dengan persentase $12,5 \%$ dan ibu hamil tidak PEB yang melahirkan bayi tidak BBLR sebanyak 14 responden dengan persentase $87,5 \%$.

Tabel 7 Hasil Analisa Bivariat

\begin{tabular}{ccccc}
\hline & Value & $\begin{array}{c}\text { Asymp. Std. } \\
\text { Error }^{\mathbf{a}}\end{array}$ & Approx. T $^{\mathbf{b}}$ & Approx. Sig. \\
\hline Spearman Correlation & .699 & .124 & 5.435 & $.000^{\mathrm{c}}$ \\
\hline & 33 & & & \\
\hline
\end{tabular}

Berdasarkan tabel di atas, untuk mengetahui hubungan variabel independent (ibu hamil dengan dengan PEB) dan variabel dependent (angka kejadian BBLR) menggunakan uji Spearman dengan nilai signifikan sebesar 0,000 $(\mathrm{p}<0,05)$ dengan koefisien korelasi spearman sebesar 0,699 yang menunjukkan koefisiensi korelasi yang kuat dan bernilai positip sehingga hal ini menunjukan adanya hubungan yang signifikan antara ibu hamil dengan PEB terhadap angka kejadian BBLR.

\section{PEMBAHASAN}

Dari hasil penelitian yang telah dilakukan dari 33 responden didapatkan umur ibu hamil kurang <20 tahun sebanyak 3 responden $(9,1 \%)$, umur 20 - 35 tahun sebanyak 19 responden $(57,6 \%)$ dan umur $>35$ tahun sebanyak 11 responden $(33,3 \%)$. Karakteristik ibu hamil berdasarkan umur terdapat pada kelompok umur 20 -35 tahun.

Usia yang dianggap aman untuk menjalani kehamilan dan persalinan adalah umur 20-35 tahun. Usia <20 tahun dan >35 tahun dianggap sebagai kelompok resiko tinggi pada kehamilan dan persalinan. Pada umur $<20$ tahun kondisi fisik terutama organ reproduksi dan psikologis belum $100 \%$ siap menjalani masa kehamilan dan persalinan, sedangkan pada umur $>35$ tahun merupakan keadaan yang dikategorikan resiko tinggi terhadap kelainan bawaan serta adanya penyulit pada masa kehamilan dan persalinan (Sulistyawati, 2011)

Menurut Depkes RI tahun 2000, umur merupakan bagian dari status reproduksi yang penting. Umur berkaitan dengan peningkatan datau penurunan fungsi tubuh yang akan berpengaruh terhadap status kesehatan seseorang. Umur yang baik untuk hamil adalah 20-35 tahun. Demikian juga seperti yang diungkapkan oleh Royston dan Amstrong (1994) bahwa umur yang paling aman bagi wanita hamil dan melahirkan adalah umur 20-35 tahun. Jadi dapat diambil kesimpulan bahwa hasil penelitian ini menunjukkan sebagian besar responden memiliki umur yang tepat untuk hamil dan melahirkan.

Dari hasil penelitian yang telah dilakukan dari 33 responden ditemukan 6 ibu hamil yang bekerja $(18,2 \%)$ dan $27 \mathrm{ibu}$ hamil yang tidak bekerja $(81,8 \%)$. Tidak bekerja di sini disebutkan bahwa ibu hamil hanya berperan sebagai Ibu Rumah Tangga (IRT).

Hasil penelitian ini sejalan dengan penelitian yang telah dilakukan oleh Saraswati dan Mardiana (2016) yang menyatakan bahwa tidak ada hubungan yang signifikan antara jenis pekerjaan ibu dengan preeklamsia pada ibu hamil. Hal ini juga diperkuat dari penelitian sebelumnya 
oleh Rozikan (2007) yang menyatakan bahwa tidak ada hubungan pekerjaan dengan kejadian preeklamsia.

Menurut Depkes RI tahun 2008, disebutkan bahwa faktor bekerja tidak terlalu memberi peran terhadap timbulnya suatu masalah pada ibu hamil akan tetapi kondisi kerja yang menonjol serta aktifitas yang berlebihan dan kurangnya istirahat saat bekerja berpengaruh besar terhadap kehamilan dan kesehatan janin yang dikandungnya. Kelompok ibu yang tidak bekerja dengan tingkat pendapatan yang rendah mengakibatkan frekuensi ANC berkurang dan kualitas gizi yang rendah.

Jadi penelitian ini dapat disimpulkan bahwa responden paling banyak adalah ibu hamil yang tidak bekerja (sebagai IRT) yang sebagian besar pada kehamilannya mengalami preeklamsia berat.

Dari hasil penelitian yang telah dilakukan dari 33 responden terdapat $6 \mathrm{ibu}$ hamil primipara $(18,2 \%)$ dan $27 \mathrm{ibu}$ hamil multipara $(81,8 \%)$. Jadi dari keseluruhan responden paling banyak adalah ibu hamil multipara.

Paritas adalah jumlah anak yang telah dilahirkan oleh seorang ibu baik dalam keadaan lahir hidup maupun lahir mati (Amiruddin, 2004). Telah diketahui bahwa usia reproduksi sehat pada seorang perempuan adalah pada umur 20-35 tahun, yang artinya hamil dan melahirkan setelah umur 20 tahun, dengan jarak kehamilan dan persalinan sebaiknya 2-3 tahun. Hal ini berkaitan dengan hasil penelitian pada karakteristik usia yang ditemukan lebih banyak pada usia reproduksi sehat yang artinya besar kemungkinan responden dalam penelitian ini sudah melahirkan lebih dari satu kali atau disebut multipara.

Dari hasil penelitian yang telah dilakukan dari 33 responden didapatkan 17 ibu hamil dengan preeklamsia berat (PEB) $(51,5 \%)$ dan 16 ibu hamil tidak PEB $(48,5 \%)$.

Pre Eklamsia merupakan gangguan multisystem pada kehamilan yang dikarakteristikkan disfungsi endothelial, peningkatan tekanan darah karena vasokontriksi, proteinuria akibat kegagalan glomerolus, dan udema akibat peningkatan permeabilitas vascular (Fauziyah, 2012).

Preeklampsia dengan tekanan darah sistolik $\geq 160 \mathrm{mmHg}$ dan tekanan darah diastolik $\geq 110 \mathrm{mmHg}$ disertai proteinuria lebih $5 \mathrm{~g} / 24$ jam disebut sebagai preeklampsia berat. Beberapa tanda dan gejala dari preeklampsia berat antara lain nyeri epigastrium, sakit kepala dan gangguan penglihatan akibat edema serebral.

Dari hasil penelitian yang telah dilakukan dari 33 responden didapatkan 16 kejadian BBLR (48,5\%) dan 17 kejadian tidak BBLR $(51,5 \%)$.

Bayi dengan BBLR adalah bayi yang lahir dengan berat badan kurang dari 2500 gram. Penyebab BBLR adalah faktor maternal, faktor janin dan faktor plasenta. Gambaran bayi dengan BBLR antara lain kulit tipis/transparan/lunak seperti gelatin, lanugo banyak atau tidak ada sama sekali, lemak subkutan sedikit, pembuluh darah terlihat jelas pada abdominal, ariole belum terbentuk dan grandula tidak teraba, telinga lunak sehingga mudah ditekuk dan pinggir tidak berlekuk, pada bayi laku-laki trstis tidak teraba sedangkan pada bayi perempuan labia minor menonjol, edema pada ekstremitas, lipat plantar halus, otot hipotonik, pernafasan belum teratur sehingga sering terjadi apnea, reflek hisap dan telan belum sempurna.

Dari hasil penelitian yang telah dilakukan didapatkan ibu hamil dengan PEB yang melahirkan bayi dengan BBLR sebanyak $14(82,4 \%)$ dan ibu hamil PEB yang melahirkan bayi tidak BBLR sebanyak 3 (17,6\%). Sedangkan ibu hamil tidak PEB yang melahirkan BBLR sebanyak $2(12,5 \%)$ dan ibu hamil tidak PEB yang melahirkan tidak BBLR sebanyak $14(87,5 \%)$.

Dari hasil analisa bivariat untuk mengetahui hubungan ibu hamil dengan 
PEB terhadap angka kejadian BBLR menggunakan uji Spearman dengan nilai signifikas sebesar $0,000(\mathrm{p}<0,05)$ dengan koefisiensi korelasi sebesar 0,699 yang menunjukkan koefisiensi korelasi yang kuat dan bernilai positip. Hal ini menunjukkan adanya hubungan yang signifikan antara ibu hamil dengan PEB terhadap angka kejadian BBLR.

Hasil penelitian ini sejalan dengan hasil penelitian yang telah dilakukan oleh Malissa, dkk (2014) yang didapatkan analisis uji statistik chi squaredi dapatkan $\mathrm{p}=0,003 \quad(\mathrm{p}<0,05)$, berarti terdapat hubungan secara statistik bermakna antara preeklampsia dengan kejadian bayi BBLR.

Demikian juga dengan hasil penelitian yang telah dilakukan oleh Lestariningsih, dkk (2013) dengan hasil yang menunjukkan ada hubungan yang signifikan anatara preeklamsia dengan kejadian BBLR (nilai $\mathrm{p}=0,000$, OR $=$ 10,11), yang artinya ibu hamil dengan preeklamsia beresiko 12,69 kali lebih besar untuk melahirkan bayi BBLR dibandingkan ibu hamil yang tidak preeklamsia.

\section{KESIMPULAN}

Penelitian ini menunjukkan adanya hubungan yang signifikan antara ibu hamil dengan PEB terhadap angka kejadian BBLR dengan koefisiensi korelasi sebesar 0,699 yang menunjukkan koefisiensi korelasi yang kuat dan bernilai positif.

\section{DAFTAR PUSTAKA}

Amirudin, R. Kandi, EP. Dkk. 2007. Current Issue Preeklamsia dan Eklamsia di Indonesia. Bagian Epidemiologi FKM UNHAS. Makasar

Badriyah, L., dan Tjahyani E. 2013. Hubungan Preeklampsia Berat dengan Kejadian Berat Bayi Lahir Rendah.

Dinkes Jateng. 2018. Profil Kesehatan Provinsi Jawa Tengah

Indrasari, N. 2012. Faktor Resiko pada Kejadian Berat Badan Lahir Rendah (BBLR). Jurnal Keperawatan. Vol. 2 No.2
Keman, Kusnarman., Patomekanisme Preeklampsia Terkini. Malang: Universitas Brawijaya Press; 2014

Kementrian Kesehatan RI. 2016. Profil Kesehatan Indonesia Tahun 2015. Jakarta. Kemenkes RI

Lestariningsih, S. 2013. Hubungan Preeklamsia Kehamilan dengan Kejadian BBLR di RSUD Jendral Ahmad Yani Kota Metro. Jurnal Kesehatan Metro Sai Wawai. Vol. 6 No. 2

Malissa, B. Towidjoyo, VD. 2014. Hubungan antara Preeklamsia dengan Kejadian BBLR di RSUD Undata Palu. Medika Tadulako. Jurnal Ilmiah Kedokteran. Vol. 1 No. 3

Manuaba, I. A. C., Manuaba, I. B. G. F., Manuaba, I. B. G. Ilmu Kebidanan, Penyakit Kandungan, dan KB Untuk Pendidikan Bidan. Jakarta: EGC; 2012

POGI. 2016. Diagnosa dan Tatalaksana Preeklamsia. Perhimpunan Obstetri Ginekologi Indonesia. Jakarta

Proverawati, A \& Ismawati, C. 2010. BBLR (Berat Badan Lagir Rendah) Plus Asuhan pada BBLR dan Materi Pijat Bayi. Nuha Media. Yogyakarta

Rochyati. Skrining Antenatal pada Ibu Hamil. Surabaya: FK UNAIR; 2011.

Saifuddin, AB. 2009. Buku Acuan Nasional Pelayanan Kesehatan Maternal dan Neonatal. PT Bina Pustaka Sarwono Prawirohardjo. Jakarta

Saraswati, N \& Mardiana. 2016. Faktor Risiko yang Berhubungan dengan Kejadian Preeklamsia pada Ibu Hamil. Unnes Journal of Public Health. Vol. 5. No. 2

Setyarini, DI \& Suprapti. 2016. Asuhan Kebidanan Kegawatdaruratan Maternal Neonatal. Pusdik SDM Kesehatan. Kementrian Kesehatan RI. Jakarta

Supiati. 2016. Karakteristik Ibu Kaitannya dengan Kejadian BBLR. Jurnal Kebidanan 
dan Kesehatan Tradisional. Vol 1. No. 1

Wiknjosastro, H. 2008. Ilmu Kebidanan. Yayasan Bina Pustaka Sarwono Prawirohardjo. Jakarta 